\title{
SOME STUDIES ON USING DIFFERENT LEVELS OF DRIED DISTILLERS GRAINS WITH SOLUBLES (DDGS) ON ANIMAL PERFORMANCE \\ 1) EFFECT OF FEEDING DIFFERENT LEVELS OF DDGS AS A SOURCE OF ENERGY ON SHEEP PERFORMANCE Etman, K.E.I.; El-Monayer, T.I; Sayed, S.K.; El-Sayed, F.A. and Mona, E. Farag \\ Animal Production Inistitute Agric - Res. Center- Ministry Of Agric.
}

\begin{abstract}
This study aimed to use dried distillers grains with solubles (DDGS) as a replacement of yellow corn in sheep rations. The trial was carried out at Animal House of Animal Production Research Institute; Agriculture Research Center, Egypt. Laboratory evaluation of seven concentrate feed mixtures (CFM) containingDDGS at the rates of $0,5,10,15,20,25$ and $30 \%$ was carried out. Rations with 10,20 and $30 \%$ DDGS as the best dry matter (DMD) and organic matter digestibility (OMD) were chosen to be used in total mixed rations and were compared with control ration in digestibility and feeding trials.

Twenty-four Rahmany lambs averaging $22.79 \mathrm{~kg}$ live body weight (LBW) were chosen and randomly divided into four similar groups (6 in each) and assigned to receive four experimental rations (A,B,C and $D$ rations) containing CFM with rate of $0,10,20$ and $30 \%$ DDGS respectively. Additionally, berseem hay $(\mathrm{BH})$ and rice straw (RS) beside CFM were offered to all animals during the trial at therate of 25: 25: 50 , respectively.

The feeding trial lasted 150 days. Body weight changes and feed intake were recorded as well as feed and economical efficiencies were estimated. Also, four digestibility trials were carried out to determine the digestibility and nutritive values of the experimental rations. Samples of rumen liquer and blood serum were taken to measure some rumen and blood parameters.

The results showed that:

1-The chemical composition of experimental rations containing different levels of DDGS was almost similar in DM, OM and NFE. It showed somewhat higher in CP and $\mathrm{EE} \%$ and lower CF\% with increasing DDGS levels.

2-Increasing DDGS level up to $30 \%$ significantly $(P<0.05)$ increased $D M, O M, C P$, EE, CF and NFE digestibilities, while increasing DDGS from 10 to $20 \%$ appeared to have higher nutrient digestibility with no significant differences, except for NFE digestibility.

3-All experimental rations containing DDGS (rations $B, C$ and $D$ ) have higher nutritive values compared with control ration (ration $A$ ). Ration D containing $30 \%$ DDGS had thethe highest $(P<0.05)$ values for TDN $(64.15 \%)$ and DCP $(9.36 \%)$ while there were no significances in the DE (2.83 MCal/ $\mathrm{Kg} \mathrm{DM})$ was not significant.

4-Averages daily gains were 109, 116, 124 and $137 \mathrm{gm} /$ day for animals fed rations $A, B, C$ and $D$, respectively, showing highly significantly $(P<0.05)$ higher gains for lambs given ration D. Increasing DDGS levels from 10 to $20 \%$ increased LBW gains with no significant differences. However, the improvements in daily gains were 6.42 , 13.76 and $25.69 \%$ with rations $B, C$ and $D$, respectively.

5-Feed utilization efficiency expressed as $\mathrm{kg}$ DM or TDN per Kg gain was significantly $(\mathrm{P}<0.05)$ higher with ration $\mathrm{D}$ containing $30 \%$ DDGS, while increasing DDGS from 10 to $20 \%$ improved feed efficiency, but not significantly. However, increasing
\end{abstract}


DDGS levels in experimental rations had no significant effecton utilization efficiency of DCP. Moreover, animals fed ration D (containing 30\% DDGS) gave the highest gross margin, revenue and economical efficiency with the lowest feed cost per kg weight gain.

6-Animals fed rations containing DDGS (rations $B, C$ and D) showed normal values of rumen and blood parameters with no adverse effects on animal performance.

Generally, it may be concluded that inclusion DDGS in the rations of growing lambs at the rate of $30 \%$ tended to increase all nutrient digestibilities and nutritive values. Moreover, lambs fed ration containing 30\% DDGS had higher weight gain, better fed utilization efficiency and lowest feed cost. The highest gross margin and revenue were recorded for the $30 \%$ DDGS rations with no adverse effect on ruminal and blood parameters.

\section{INTRODUCTION}

Dried distillers grains with solubles (DDGS) is a co-product of ethanol industry. DDGS can be produced from cereals such as corn, sorghum or wheat. Corn DDGS is a high in energy and protein contents, but low in starch content compared with the original grain s (NRC, 2007). The DDGS is also a good source of energy and is a source of highly digestible fiber (AlSuwaieghet al., 2002). Most of corn starch from the original grain is removed during the fermentation process. Replacing a portion of the corn in a traditional diet with DDGS shifts the ingested energy source from starch to digestible fiber and fat (Ham et al., 1994).Carvalhoet al. (2005) and Nearyet al. (2006) found that the DDGS had high energy value, good digestibility of fat and crude fiber, while Archibequeet al. (2008) reported improvements in nutritional values when DDGS were supplemented to cereals (Wheat or corn) to be appropriate for combination with low-quality roughages in sheep ration. Sahinet al. (2013) evaluated the effect of DDGS incorporated to the concentrate ration in growing lambs on weight growth, feed consumption and efficiency, nutrient digestibility and some rumen parameters. They found that feeding DDGS at up to $20 \%$ of growing lamb ration appeared to have no negative effects on growth performance. They added that the rumen $\mathrm{pH}$ and $\mathrm{NH}_{3}-\mathrm{N}$ values were similar with those reported by Wertz-Lutz et al. (2007) when animals fed soybean and DDGS at different rations in the diet with no significant differences. Also, Sahinet al. (2013) and O'Hara et al. (2011) reported no change in VFA's concentration with lambs fed DDGS as supplementation during finishing period.Radev (2012) showed that the inclusion of DDGS in the animals ration resulted in significant $(P<0.05)$ increase in rumen ammonia and total VFA's concentration. Some studies on the effect of DDGS on the fattening performance, weight gain and meat quality in small ruminant have been performed. Estrada- Angulo et al. (2007) showed no significant differences in the weight gain and feed utilization after substitution of 15 to $35 \%$ of corn and soybean meal by DDGS in yearling sheep ration. Held (2006) observed that the addition of DDGS to the diet of yearling rams at the end of the fattening period did not influence their weight. Shaueret al. (2006) showed no negative impact on feed intake, growth or carcass traits when DDGS was mixed with cereal with rate of $>22.5 \%$ for finishing lambs. On the other hand, Felix et al. (2012) studied the effect of 
feeding $0,20,40$ and $60 \%$ dried distiller grains with solubles (DDGS) on growing lamb performance, carcass characteristics and nutrient digestibility. They found that lambs fed the 20\% DDGS diet had the greatest gain $(0.358$ $\mathrm{kg} /$ day). This effect on average daily gain led to a quadratic effect of DDGS on final body weight and increasing dietary DDGS did not effect on dry mater intake. They also showed that increasing in dietary DDGS resulted in decreased digestion of DM and fat, which may be partially responsible for decreased lamb feedlot performance at 40 and 60\% dietary DDGS when compared with $20 \%$ DDGS.

This study was carried out to evaluate the effect of using different levels of dried distiller grain with solubles in ration of growing fat-tailed lambs on performance, digestibility and nutritive value. Ruminal and blood parameters as well as feed and economical efficiencies were also examined.

\section{MATERIALS AND METHODS}

This study aimed to use different levels of DDGS to replace yellow corn as a source of energy in fat-tailed sheep rations. The experimental work was carried out at Animal House of the Animal Production Research Institute, Agriculture Research Center, Egypt.

Before starting the feeding trial, seven percentages of DDGS $(0,5$, $10,15,20,25$ and $30 \%$ ) were incorporated to makeseven concentrate feed mixtures. Laboratory evaluation of theseven concentrate feed mixtures were carried out using In vitro trial. After words, three different concentrate feed mixtures containing DDGS at the rate of 10,20 and $30 \%$ with the best of DMD and OMD were chosen and used to make total mixed ration (TMR) for comparing them with control ration containing zero percentage of DDGS.

Twenty four Rhamany lambs averaging $22.79 \mathrm{~kg}$ live body weight were chosen and used in feeding trial. Animals were divided into four similar groups (6 in each) and assigned to receive four experimental rations containing concentrate feed mixture, berseem hay and rice straw at the rate of 50: 25: 25, respectively, according to NRC (2007). The concentrate feed mixture was offered to animals twice daily at 8.00 a.m. and 3.00 p.m.followed by berseem hay, while rice straw and water were available during the whole day. The experimental rations were formulated to be isonitrogenous and isoenergetic. The feeding trial lasted 150 days in which, changes of body weight and feed intake were recorded. On the other hand, twelve Rahmany rams averaging $45 \mathrm{~kg}$ LBW were used in four digestibility trials (3 rams in each) to determine digestibility coefficients and nutritive values of experimental rations. Each digestibility trial lasted for three weeks, the first two weeks were used as a preliminary period, followed by one week for feces collection. Animals were fed twice daily at 8.00 a.m. and 3.00 p.m. according to NRC (2007), while water was offered ad-lib. Samples of feed intake and feces were taken and analyzed according to A.O.A.C. (2000). Digestion coefficients of all nutrients and feeding values were calculated according to Abou-Raya (1967). Rumen liquor samples were taken from the same animals of the digestibility trial at $3 \mathrm{hr}$ after feeding using stomach tube. Part of 
collected rumen liquor samples was directly tested for $\mathrm{pH}$ values using orian 680 digital $\mathrm{pH}$ meter, while the other part was preserved in dry clean glassbottles with addition 2 drops of mercuric chloride to determine totalnitrogen (TN), protein-nitrogen (PN) and ammonia- nitrogen $\left(\mathrm{NH}_{3}-\mathrm{N}\right)$ concentrations according to A.O.A.C. (2000), but the volatile fatty acids (VFA's) concentration were determined according to Eadieet al. (1967). Blood samples were collected from jugular vein of the same animals of digestibility trial at $3 \mathrm{hr}$ after feeding. Blood samples were immediately centrifuged at 3000 r.p.m. for 20 minutes. Serum was separated from blood and kept it in frozen at $-20^{\circ} \mathrm{C}$ for chemical analysis to determine total protein (Cornell et al., 1949), albumin (Drupt, 1974) while globulin concentration was determine by differences between total protein and albumin concentration. Creatinin concentration was determined according to Young (1990). AST and ALT activities were determined as described by Reitman and Frankel (1957). Urea concentration was determined according to Fawcett and Scott (1960). The data were statistically analyzed by using general linear model (GLM) procedure according to Statistical Analysis System (SAS, 2000). The differences among means were tested using Duncan Multiple range test (Duncan, 1955).

\section{RESULTS AND DISCUSSION}

\section{Effect of DDGS inclusion with different levels in sheep rations}

The data presented in Table (1) showed that the DDGS was incorporated in CFM as the rate of $0,5,10,15,20,25$ and $30 \%$ to cover 0,6 , $12,18,25,30$ and $35 \%$ of energy, respectively.

Table (1):Composition of the concentrate feed mixture containing different levels of DDGS.

\begin{tabular}{|c|c|c|c|c|c|c|c|}
\hline \multirow{2}{*}{ Items } & \multicolumn{7}{|c|}{${ }^{*}$ Component of CFM } \\
\hline & 1 & 2 & 3 & 4 & 5 & 6 & 7 \\
\hline \multicolumn{8}{|l|}{ Ingredients : } \\
\hline Yellow corn & 40 & 35 & 30 & 25 & 20 & 15 & 10 \\
\hline Sunflower cake & 30 & 27 & 25 & 18 & 12 & 6 & - \\
\hline Wheat bran & 17 & 20 & 22 & 25 & 27 & 23 & 12 \\
\hline Rice bran & 10 & 10 & 10 & 14 & 18 & 28 & 45 \\
\hline ** DDGS & 0 & 5 & 10 & 15 & 20 & 25 & 30 \\
\hline Lime stone & 2 & 2 & 2 & 2 & 2 & 2 & 2 \\
\hline Salt & 1 & 1 & 1 & 1 & 1 & 1 & 1 \\
\hline
\end{tabular}

** DDGS: Dried distillers grains with solubles

It could be noticed that, all nutrient composition of CFM containing DDGS were almost similar and showed somewhat higher in DM, CP and EE, while CF, NFE and OM percentages were lower compared with the control ration, as shown in Table (2).

The data revealed that, increasing DDGS levels in CFM increased $\mathrm{CP}$ and EE and decreased both of CF and NFE contents. The increase and decrease of some nutrients of CFM might be due to chemical composition of DDGS (Table 2). Also, it could be noticed that the CFM containing DDGS at 
the rate of 10,20 and $30 \%$ gave the best DMD, being $86.62,87.65$ and 88.76 respectively. Corresponding values of OMD showed the similar trend, being 92.34, 92.56 and $92.68 \%$, respectively, as shown in Table (2). On the other hand, chemical composition of berseem hay, rice straw and DDGS were similar to those reported by Shwerabet al. (2010) and Etmanet al. (2010, 2011).

Table(2):Chemical compositionof berseem hay, rice straw,DDGS,CFM with or without DDGS and DMD\&OMD digestibility of different CFM.

\begin{tabular}{|c|c|c|c|c|c|c|c|c|c|}
\hline \multirow{2}{*}{ Items } & \multirow{2}{*}{$\begin{array}{l}\text { DM } \\
\%\end{array}$} & \multicolumn{5}{|c|}{ Composition of MD (\%) } & \multirow{2}{*}{$\begin{array}{l}\text { OM } \\
\%\end{array}$} & \multicolumn{2}{|c|}{$\begin{array}{c}\text { Digestibility * } \\
(\%)\end{array}$} \\
\hline & & $\mathbf{C P}$ & EE & CF & NFE & Ash & & DMD & OMD \\
\hline Berseem hay $(\mathrm{BH})$ & 91.75 & 15.50 & 3.02 & 24.14 & 47.52 & 9.82 & 90.18 & & \\
\hline Rice Straw (RS) & 90.80 & 3.48 & 1.42 & 43.15 & 40.91 & 11.04 & 88.96 & & \\
\hline DDGS & 91.20 & 26.85 & 8.14 & 9.13 & 51.68 & 4.20 & 95.80 & & \\
\hline CFM containing $0 \%$ DDGS & 86.08 & 15.43 & 2.92 & 11.78 & 62.98 & 6.89 & 93.11 & 85.12 & 92.25 \\
\hline CFM containing 5\% DDGS & 86.32 & 16.00 & 3.21 & 11.67 & 61.96 & 7.16 & 92.84 & 85.35 & 92.11 \\
\hline CFM containing $10 \%$ DDGS & 86.48 & 16.71 & 3.49 & 11.70 & 60.66 & 7.44 & 94.26 & 86.62 & 92.34 \\
\hline CFM containing $15 \%$ DDGS & 86.36 & 16.72 & 3.75 & 11.19 & 60.03 & 7.71 & 92.29 & 86.44 & 92.27 \\
\hline CFM containing $20 \%$ DDGS & 87.76 & 16.87 & 3.99 & 10.81 & 60.34 & 7.99 & 92.01 & 87.65 & 92.56 \\
\hline CFM containing $25 \%$ DDGS & 88.54 & 16.95 & 4.07 & 10.67 & 60.01 & 8.30 & 91.70 & 87.60 & 92.52 \\
\hline CFM containing $30 \%$ DDGS & 89.53 & 16.97 & 3.95 & 10.81 & 59.65 & 8.62 & 91.38 & 88.76 & 92.68 \\
\hline
\end{tabular}

Feed intakes, composition, digestibility and feeding value:

The data presented in table (3) showed that average daily feed intake $(\mathrm{kgDM} / \mathrm{head})$ increased with increasing DDGS levels, being 1.487, 1.545, 1.606 and $1.685 \mathrm{~kg} \mathrm{DM} /$ head for rations $A, B, C$ and $D$ which contain 0,10 , 20 and $30 \%$ DDGS, respectively. At the same time,berseem hay and rice straw intakes increased with increasing dietry DDGS levels, probably due to better palatablity of DDGS. The calculated composition of experimental rations showed that, increasing DDGS percentages tended to increase of DM, CP and EE\%, while OM, CF and NFE\% appeared to have somewhat lower percentages. The experimental ration containing 30\% DDGS (ration D) showed the highest CP\% and the lowest CF\% (Table 3). Therefor, gradual increase of dietary DDGS levels in experimental rations increased CP and decreased CF contents, as shown in Table (3).

The results obtained revealed that, the digestibility coefficients of tested rations $(B, C$ and $D)$ was significantly $(P<0.05)$ higher of all nutrients compared with the control ration (ration $A$ ). The digestibility coefficients of $\mathrm{CP}$ recorded $68.18,68.40,68.96$ and $70.84 \%$ for rations $A, B, C$ and $D$, respectively, with the highest significant $(P<0.05)$ value for ration $D(30 \%$ DDGS). The same higher $(P<0.05)$ significant value was observed for $D M$, $\mathrm{OM}, \mathrm{EE}, \mathrm{CF}$ and NFE digestibility for ration D (Table 3). Also, increasing DDGS levels from 20 to $30 \%$ appeared to significantly $(P<0.05)$ increase in digestibility of all nutrients with no significant differences, except for NFE digestibility. However, inclusion DDGS at the rate of $10 \%$ (Ration B) led to higher $\mathrm{DM}, \mathrm{OM}, \mathrm{CP}$ and NFE digestibility than control ration with no significant differences. 
Table (3):Average daily feed consumption, calculated feed composition, digestibility coefficients and feeding values of experimental rations.

\begin{tabular}{|c|c|c|c|c|c|}
\hline \multirow{2}{*}{ Items } & \multicolumn{4}{|c|}{ Experimental rations containing DDGS ${ }^{\star}$} & \multirow{2}{*}{$\begin{array}{c}\text { Significant } \\
\text { level }\end{array}$} \\
\hline & A & B & C & D & \\
\hline \multicolumn{6}{|l|}{ 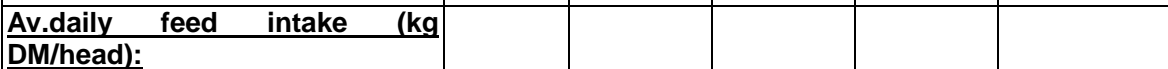 } \\
\hline 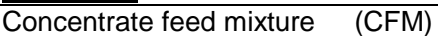 & 0.781 & 0.795 & 0.826 & 0.867 & \\
\hline $\begin{array}{l}\text { Berseem hay } \\
(\mathrm{BH})\end{array}$ & 0.336 & 0.373 & 0.388 & 0.407 & \\
\hline Rice straw ( RS) & 0.370 & 0.377 & 0.392 & 0.411 & \\
\hline Total DM intake & 1.487 & 1.545 & 1.606 & 1.685 & \\
\hline \multicolumn{6}{|c|}{$\begin{array}{l}\text { Calculated composition of experimental } \\
\text { rations: }\end{array}$} \\
\hline DM & 88.51 & 88.78 & 89.48 & 89.47 & \\
\hline OM & 91.43 & 91.12 & 90.81 & 90.60 & \\
\hline $\mathrm{CP}$ & 12.46 & 13.15 & 13.19 & 13.21 & \\
\hline $\mathrm{EE}$ & 2.57 & 2.87 & 3.11 & 3.07 & \\
\hline CF & 22.34 & 22.23 & 22.09 & 21.66 & \\
\hline NFE & 54.06 & 52.87 & 52.42 & 52.66 & \\
\hline \multirow{2}{*}{\multicolumn{6}{|c|}{$\begin{array}{l}\text { Digestibility coefficients of experimental } \\
\text { rations: }\end{array}$}} \\
\hline & & & & & \\
\hline DM & $68.15^{\mathrm{b}}$ & $68.50^{\mathrm{b}}$ & $68.90^{\mathrm{b}}$ & $70.45^{\mathrm{a}}$ & $(P<0.05)$ \\
\hline OM & $70.82^{b}$ & $70.94^{\mathrm{b}}$ & $71.08^{b}$ & $72.13^{\mathrm{a}}$ & $(\mathrm{P}<0.05)$ \\
\hline $\mathrm{CP}$ & $68.18^{b}$ & $68.40^{\mathrm{b}}$ & $68.96^{b}$ & $70.84^{\mathrm{a}}$ & $(P<0.05)$ \\
\hline $\mathrm{EE}$ & $60.20^{c}$ & $60.70^{\mathrm{b}}$ & $60.74^{\mathrm{b}}$ & $61.92^{\mathrm{a}}$ & $(P<0.05)$ \\
\hline CF & $56.74^{c}$ & $57.15^{\mathrm{b}}$ & $57.83^{\mathrm{b}}$ & $58.94^{\mathrm{a}}$ & $(\mathrm{P}<0.05)$ \\
\hline NFE & $69.12^{c}$ & $69.51^{c}$ & $70.04^{b}$ & $71.67^{\mathrm{a}}$ & $(\mathrm{P}<0.05)$ \\
\hline \multicolumn{6}{|l|}{ Feeding values: } \\
\hline TDN (\%) & $62.04^{\mathrm{b}}$ & $62.29^{b}$ & $62.83^{a}$ & $64.15^{\mathrm{a}}$ & $(P<0.05)$ \\
\hline $\mathrm{DCP}(\%)$ & $8.50^{\mathrm{b}}$ & $8.99^{\mathrm{b}}$ & $9.10^{\mathrm{a}}$ & $9.36^{\mathrm{a}}$ & $(P<0.05)$ \\
\hline${ }^{* \star} \mathrm{DE}(\mathrm{M} \mathrm{Cal} / \mathrm{Kg} \mathrm{DM})$ & 2.74 & 2.75 & 2.77 & 2.83 & NS \\
\hline
\end{tabular}

a, $b$ and $c$ : Means in the same raw with different superscripts are significant $(P<0.05)$ differed.

* $\mathrm{A}: \mathrm{BH}+\mathrm{RS}+\mathrm{CFM}$ containing $0 \%$ DDGS

B: $B H+R S$ + CFM containing $10 \%$ DDGS

C: $\mathrm{BH}+\mathrm{RS}+\mathrm{CFM}$ containing $20 \%$ DDGS

** DE was calculated as mentioned by Church and Pond (1982)

The feeding values of experimental rations expressed as TDN (\%), DCP (\%) and DE (MCal/Kg DM) are presented in Table (3). The TDN values were $62.04,62.29,62.83$ and $64.15 \%$ for rations $A, B, C$ and $D$, respectively. Corresponding values of DCP were $8.50,8.99,9.10$ and $9.36 \%$ versus 2.74 , $2.75,2.77$ and $2.83 \mathrm{Mcal} / \mathrm{Kg}$ DM as DE for the respective rations. The results obtained revealed that increasing DDGS percentages in CFM of experimental rations tended to increase TDN and DCP. There were significant $(P<0.05)$ increase in feeding values when DDGS adding at the rate of 20 and $30 \%$ in rations $C$ and $D$, respectively. The inclusion of DDGS at the rate of $10 \%$ appeared to increase the TDN and DCP with no significant differences (Table 3). Also, the data showed that $D E(M \mathrm{Cal} / \mathrm{Kg} \mathrm{DM})$ increased with increasing DDGS levels in rations with no significant differences.

The present results were agreement with those reported by Shwerabet al.(2010) and Etmanet al. $(2010,2011)$. They found an increase in 
digestibility coefficients and feeding values of rations containing DDGS. The increase and improvement in the digestibility coefficients and nutritive value of rations containing DDGS might be attributed to higher availability of the nutrient contents of DDGS as reported by Leuppet al. (2009), May et al. (2009) and Shaueret al. (2006).

\section{Animal performance and feed utilization efficiency:}

The results presented in Table (4) showed significantly $(P<0.05)$ higher daily LBW gains, being 109, 116, 124 and 137gm with animals fed rations $A, B, C$ and $D$, respectively compared with those fed the control ration. The improvements in daily LBW gains were $6.42,13.76$ and $25.69 \%$ when DDGS was included at the rate of 10,20 and $30 \%$, respectively, showing the greatest improvement with animals fed ration D (30\% DDGS). The highest improvement in daily LBW gains recorded for animals fed ration $D$ might be due to higher feed unite intake in terms of DM, TDN and DCP, as shown in Table (4). Animals fed rations containing DDGS (rations $B, C$ and $D)$ had higher feed intakes than those fed control ration. This might be due to the higher digestibility coefficients, feeding values and better palatability of rations conaining DDGS(Schaueret al. (2008), Etmanet al. (2010), Lopez et al. (2010), Vander et al. (2005) and Felix et al. (2012).

Table (4): Performance and feed utilization efficiency of sheep fed different experimental rations.

\begin{tabular}{|l|c|c|c|c|c|}
\hline \multirow{2}{*}{ Items } & \multicolumn{4}{|c|}{ Experimental rations } & \multirow{2}{*}{$\begin{array}{c}\text { Significant } \\
\text { level }\end{array}$} \\
\cline { 2 - 5 } & A & B & C & D & \\
\hline No. of animals & 6 & 6 & 6 & 6 & \\
\hline Experimenta period (day) & 150 & 150 & 150 & 150 & \\
\hline Av. Initial LBW (kg) & 22.85 & 22.90 & 22.75 & 22.65 & \\
\hline Av. Final LBW (kg) & 39.20 & 40.24 & 41.35 & 43.20 & \\
\hline Av.Total LBW gains(kg) & 16.35 & 17.34 & 18.60 & 20.55 & \\
\hline Av daily LBW gains (kg) & $109^{\mathrm{c}}$ & $116^{\mathrm{bc}}$ & $124^{\mathrm{b}}$ & $137^{\mathrm{a}}$ & $(\mathrm{P}<0.05)$ \\
\hline Improvement (\%) & - & 6.42 & 13.76 & 25.69 & \\
\hline Av. daily feed unit intake: & & & & & \\
\hline \hline Kg DM/ head & 1.292 & 1.340 & 1.404 & 1.492 & \\
\hline Kg TDN/ head & 0.802 & 0.835 & 0.882 & 0.957 & \\
\hline Kg DCP/ head & 0.110 & 0.120 & 0.128 & 0.140 & \\
\hline Feed utilization efficiency: & & & & & \\
\hline Kg DM/ head & $11.853^{\mathrm{a}}$ & $11.552^{\mathrm{b}}$ & $11.323^{\mathrm{b}}$ & $10.891^{\mathrm{c}}$ & $(\mathrm{P}<0.05)$ \\
\hline Kg TDN/ head & $7.358^{\mathrm{a}}$ & $7.198^{\mathrm{b}}$ & $7.113^{\mathrm{b}}$ & $6.985^{\mathrm{c}}$ & $(\mathrm{P}<0.05)$ \\
\hline Kg DCP/ head & $1.009^{\mathrm{b}}$ & $1.034^{\mathrm{a}}$ & $1.032^{\mathrm{a}}$ & $1.022^{\mathrm{a}}$ & $(\mathrm{P}<0.05)$ \\
\hline
\end{tabular}

a, $b$ and $c:$ Means in the same raw with different superscripts are significant $(P<0.05)$ differed.

The feed utilization efficiency expressed as Kg DM, TDN or DCP per $\mathrm{Kg}$ gain are shown in Table (4). There were significant $(\mathrm{P}<0.05)$ differences in feed utilization efficiency. The best values were recorded for animals fed ration $D$ with. Also, the significant $(P<0.05)$ differences in utilization efficiency of DCP were observed between animals fed rations containing DDGS and those fed control ration. However, increasing DDGS levels from 10 to $30 \%$ had no significant affect on feed utilization efficiency as $\mathrm{Kg} \mathrm{DCP} / \mathrm{Kg}$ gain 
(Table 4). The present data revealed that the increased daily LBW gains for rations containing DDGS was associated with better utilization efficiency as $\mathrm{Kg}$ DM or TDN per $\mathrm{Kg}$ gain. This increase might be attributed to higher digestibility nutrients, nutritive values and increase in feed unite intakes.

Generally, animals fed ration D containing 30\% DDGS as a source of energy had the highest average daily LBW gain with the best feed utilization efficiency as $\mathrm{Kg}$ DM or TDN per $\mathrm{Kg}$ gain. These results were in agreement with those reported by Reed et al. (2006), Etmanet al. $(2010,2011)$ and Felix et al. (2012).

\section{Feed cost and economical efficiency:}

The results presented in Table (5) revealed that the feed cost $/ \mathrm{kg}$ gains gradually increased with increasing DDGS levels in experimental rations, being 2.505, 2.585, 2.702 and $2.853 \mathrm{LE}$ for animals fed rations $\mathrm{A}, \mathrm{B}$, $\mathrm{C}$ and D, respectively. However, ration containing $30 \%$ DDGS (ration D) had the lowest feed cost/ kg gain compared with the control ration , being 20.825 and 22.982LE, respectively. Consequently, the revenue increased with increasing DDGS levels in the experimental rations, recording $0.983,1.127$, 1.266 and $1.531 \mathrm{LE} /$ head/ day, with animals fed rations $A, B, C$ and $D$, respectively. Corresponding gross margin above feed cost showed the same trend, recording improvement by $11.22,19.64$ and $36.99 \%$ with rations $\mathrm{B}, \mathrm{C}$ and $D$, respectively. Also, rations containing DDGS showed better economical efficiency than thatof the control. The economical efficiency were $1.392,1.434,1.469$ and 1.537 with rations $A, B, C$ and $D$, respectively, showing the highest improvement in economical efficiency for ration $D$ $(10.42 \%)$.

Table (5):Average daily feed intake, daily gain, feed cost and economical efficiency

\begin{tabular}{|l|c|c|c|c|}
\hline \multirow{2}{*}{ Items } & \multicolumn{4}{|c|}{ Experimental rations } \\
\cline { 2 - 5 } & A & B & C & D \\
\hline Av. daily feed intake, as fed (kg): & & & & \\
\hline Concentrate feed mixture & 0.760 & 0.785 & 0.816 & 0.858 \\
\hline Berseem hay & 0.344 & 0.363 & 0.374 & 0.395 \\
\hline Rice straw & 0.355 & 0.365 & 0.380 & 0.399 \\
\hline Av daily LBW gains (kg) & 0.109 & 0.116 & 0.124 & 0.137 \\
\hline${ }^{*}$ Cost of feed intake (LE) & 2.505 & 2.585 & 2.702 & 2.853 \\
\hline Price of LBW gain (LE) & 3.488 & 3.712 & 3.968 & 4.384 \\
\hline Feed cost/ kg weight gain (LE) & 22.982 & 22.284 & 21.790 & 20.825 \\
\hline Revenue (LE/ head/ day) & 0.983 & 1.127 & 1.266 & 1.531 \\
\hline Gross margin above feed cost (LE) & 0.392 & 0.436 & 0.469 & 0.537 \\
\hline Improvement of gross margin (\%) & - & 11.22 & 19.64 & 36.99 \\
\hline Economical efficiency & 1.392 & 1.436 & 1.469 & 1.537 \\
\hline Improvement of economical efficiency (\%) & - & 3.02 & 5.53 & 10.42 \\
\hline \multirow{*}{*}{ Based on the assumption that the price of one ton of berseem hay, rice straw, }
\end{tabular}

* Based on the assumption that the price of one ton of berseem hay, rice straw, concentrate feed mixture containing DDGS with rate of $0,10,20$ and $30 \%$ was 1700,400 , $2340,2325,2345$ and $2355 \mathrm{LE}$, respectively and the price of one $\mathrm{kg}$ live body weight in selling was 32 LE.

Generally, increasing DDGS levels in experimental rations tended to have higher revenue, gross margin and economical efficiency and lower feed 
cost. These results were agreement with those reported by Etmanet al. (2010, 2011) and Shwerabet al. (2010).

\section{Ruminal Parameters:}

Rumen parameters such as $\mathrm{pH}, \mathrm{VFA}$ 's, TN, $\mathrm{NH}_{3}-\mathrm{N}, \mathrm{PN}$ and NPN are presented in Table (6). The results showed that, adding DDGS as a source of energy to the experimental rations had no significant affect on $\mathrm{pH}$ value and PN concentration, while total VFA's showed significantly $(P<0.05)$ higher concentration, recording 11.42, 11.52, 11.75 and $11.94 \mathrm{meq} / 100 \mathrm{ml}$ for rations $A, B, C$ and $D$, respectively. Similar trend was observed with $\mathrm{TN}, \mathrm{NH}_{3}-$ $\mathrm{N}$ and NPN concentrations. The present results revealed that increasing DDGS levels from 10 to $20 \%$ in CFM did not significantly effect on rumen parameters. Increasing DDGS levels from 20 to $30 \%$ resulted in significantly $(\mathrm{P}<0.05)$ higher rumen parameters as shown in Table (6). Animals fed ration containing 30\% DDGS (ration D) had the highest pH, VFA's, $\mathrm{NH}_{3}-\mathrm{N}$ and PN concentrations. At the same time, animals fed control ration(without DDGS) had the highest TN and NPN concentrations. Johnson and Suttan (1968) reported that the $\mathrm{pH}$ values were affected by dietary levels and/ or the sources of CP and carbohydrate.Allamet al. (1984) showed that the VFA's concentration in rumen liquor was affected by several factors such as DM digestibility, rate of absorption, rumen $\mathrm{pH}$, transportation of the digesta from the rumen to the lower part of the digestive tract and microbial population in the rumen and their activities. Arelovichet al. (2000) and Shakweeret al. (2010) reported that the increase in total VFA's concentration might be due to increase in apparent digestibility of organic matter. Similar results were observed by Etmanet al. (2011) who found that increasing in total VFA's, TN, $\mathrm{NH}_{3}-\mathrm{N}$ concentrations of rumen liquor were attributed to higher levels of DDGS in rations for fattening buffalo calves. On the other hand, Faichney and White (1977) and Etmanet al. (2012) found that rations containing higher levels of protein resulted in higher $\mathrm{NH}_{3}-\mathrm{N}$ concentration in rumen.

Table (6):Overall mean of rumen parameters of animals fed different experimental rations.

\begin{tabular}{|c|c|c|c|c|c|}
\hline \multirow{2}{*}{ Items } & \multicolumn{4}{|c|}{ Experimental rations } & \multirow{2}{*}{$\begin{array}{c}\text { Significant } \\
\text { level }\end{array}$} \\
\hline & $\mathbf{A}$ & B & C & D & \\
\hline $\mathrm{pH}$ values & 6.14 & 6.22 & 6.29 & 6.32 & NS \\
\hline Total VFA's(meq/ 100ml) & $11.42^{\mathrm{b}}$ & $11.52^{\mathrm{b}}$ & $11.75^{\mathrm{a}}$ & $11.94^{\mathrm{a}}$ & $(\mathrm{P}<0.05)$ \\
\hline Total $-\mathrm{N} \quad(\mathrm{mg} / 100 \mathrm{ml})$ & $117.15^{a}$ & $110.72^{b}$ & $112.86^{b}$ & $116.32^{\mathrm{a}}$ & $(\mathrm{P}<0.05)$ \\
\hline $\mathrm{NH}_{3}-\mathrm{N} \quad(\mathrm{mg} / 100 \mathrm{ml})$ & $16.84^{c}$ & $17.12^{\mathrm{b}}$ & $17.15^{\mathrm{b}}$ & $17.96^{\mathrm{a}}$ & $(\mathrm{P}<0.05)$ \\
\hline Protein- N (mg/ 100ml) & 82.18 & 82.60 & 84.49 & 84.97 & NS \\
\hline NPN $\quad(\mathrm{mg} / 100 \mathrm{ml})$ & $34.97^{a}$ & $28.12^{\mathrm{b}}$ & $28.37^{b}$ & $31.35^{a}$ & $(\mathrm{P}<0.05)$ \\
\hline
\end{tabular}

a, b and c: Means in the same raw with different superscripts are significant $(P<0.05)$ differed.

The results presented in Table (6) revealed that the high protein $-\mathrm{N}$ concentration in rumen liquor of animals fed rations containing DDGS (rations $\mathrm{B}, \mathrm{C}$ and $\mathrm{D}$ ) could be explained by somewhat higher percentages $\mathrm{CP}$ for those rations than that of control ration (without DDGS). Also, higher PN concentration might be due to increase uptake of ammonia by the rumen 
microflora and according to the higher rate of microbial protein synthesis, however, differences in PN concentration were not significant.

Generally, it could be noticed that, animals fed ration containing $30 \%$ DDGS (ration D) showed significantly $(\mathrm{P}<0.05)$ higher total VFA's, $\mathrm{TN}, \mathrm{NH}_{3}-\mathrm{N}$ and NPN concentrations, while the increase in $\mathrm{pH}$ values and $\mathrm{PN}$ concentration were not significant. The fluctuations in $\mathrm{pH}$ values, $\mathrm{NH}_{3}-\mathrm{N}$ and VFA's concentrations could be attributed to different factors such as ration composition, feeding type and its level and roughage to concentrate ratio (Etmanet al. 2011 and 2012).

The present results were agreement with those reported by Mohi-E Din et al. (2008), El-Nahas (2010) and Etmanet al. (2012), but Shwerabet al. (2010) who showed lower $\mathrm{NH}_{3}-\mathrm{N}$ and VFA's concentrations with increasing DDGS levels in sheep rations.

\section{Blood Measurements:}

The results presented in Table (7) showed that serum total protein increased with increasing DDGS levels, being 6.48, 6.52, 6.64 and $6.76 \mathrm{gm} / \mathrm{dl}$ for animals fed rations $A, B, C$ and $D$, respectively. Corresponding values of albumin were $3.86,3.89,3.92$ and $3.98 \mathrm{gm} / \mathrm{dl}$, while globulin concentrations were 2.62, 2.63, 2.72 and $2.78 \mathrm{gm} / \mathrm{dl}$ for the respective rations. However, these differences were not statistically significant. It could be observed that higher concentration of serum total protein, albumin and globulin which recorded for animals fed rations containing DDGS might be attributed to improve nitrogen absorption (Kornegayet al., 1997) and increase CP digestibility (Yousef and Zaki; 2001; Etmanet al., 2012). At the same time, Kumar et al. (1980) showed positive correlation between dietary protein and serum protein concentration. Consequently, GOT and GPT concentrations showed significantly $(P<0.05)$ higher values with increasing DDGS levels. In this respect, Boots et al. (1969) reported that GOT and GPT concentrations depends on several factors such as: feeding practices, genetic control, response to stress age, liver function and body weight. On the contrary, creatinin and urea- $\mathrm{N}$ concentration in sheep blood decreased with increasing DDGS levels with no significant differences as shown in Table( 7).

Table (7): Blood parameters of sheep fed different experimental rations.

\begin{tabular}{|c|c|c|c|c|c|}
\hline \multirow{2}{*}{ Items } & \multicolumn{4}{|c|}{ Experimental rations } & \multirow{2}{*}{$\begin{array}{c}\text { Significant } \\
\text { level }\end{array}$} \\
\hline & $\mathbf{A}$ & B & C & D & \\
\hline \multicolumn{6}{|c|}{ Serum protein $(\mathrm{gm} / \mathrm{dl}):$} \\
\hline Total protein & 6.48 & 6.52 & 6.64 & 6.76 & NS \\
\hline Albumin $(A)$ & 3.86 & 3.89 & 3.92 & 3.98 & NS \\
\hline Globulin (G) & 2.62 & 2.63 & 2.72 & 2.78 & \\
\hline $\mathrm{A} / \mathrm{G}$ ratio & 1.47 & 1.48 & 1.44 & 1.43 & \\
\hline \multicolumn{6}{|l|}{ Liver function : } \\
\hline GOT (AST), IU/ L & $35.14^{b}$ & $39.12^{\mathrm{a}}$ & $40.15^{\mathrm{a}}$ & $41.06^{\mathrm{a}}$ & $(P<0.05)$ \\
\hline GPT (ALT), IU/L & $25.28^{b}$ & $30.07^{a}$ & $31.18^{\mathrm{a}}$ & $32.58^{\mathrm{a}}$ & $(\mathrm{P}<0.05)$ \\
\hline \multicolumn{6}{|l|}{ Kidney function: } \\
\hline Creatinin $(\mathrm{mg} / \mathrm{dl})$ & 1.30 & 1.28 & 1.22 & 1.21 & NS \\
\hline Urea-N (mg/100ml) & 14.72 & 14.58 & 14.22 & 13.98 & NS \\
\hline
\end{tabular}

$a$ and $b$ : Means in the same raw with different superscripts are significant $(P<0.05$ differed 
In general, increasing DDGS levels from 10 to $30 \%$ had no significant effect on total protein and its fractions, liver and kidney functions. These results were in agreement with those reported by Mohi-EL Din et al. (2008), Lopez et al. (2010), Etmanet al. (2011 and 2012).

\section{CONCLUSION}

The dried distillers grains with solubles (DDGS) could be used as a source of energy to replace a part of yellow corn in concentrate feed mixture for growing lambs. DDGS could be included at the rate of $30 \%$ to cover about $35 \%$ energy of the concentrate feed mixture. Using DDGS at the rate of $30 \%$ in sheep rations had higher nutrient digestibility, nutritive value and daily LBW gains. Moreover, DDGS makes a better feed utilization efficiency and lower feed cost to get one kg gain with higher gross margin and revenue. Further work is needed to explore the possibility of including DDGS at higher level in sheep rations as a substitution of both energy and protein.

\section{REFERENCES}

A.O.A.C. (2000). Association of Official Analytical Chemists. Official Methods of Analysis. Washington, D.C., USA.

Abou-Raya, A.K. (1967). Animal and Poultry Nutrition, In Arabic, April, Cairo, Egypt.

Allam, S.M.; A.K. Abou-Raya; E.A. Gihad and T.M. El-Bedawy (1984). Nutritional studies by sheep and goats fed $\mathrm{NaOH}$ treated straw. $1^{\text {st }}$ Egyptian-British Conf. Anim. and Poultry Prod., Zagazig Univ., 11-13 Sept., P.53.

Al-Suwaiegh, S., K.C. Fanning; R.J. Grant; C.T. Miton and T.J. Klopfenstein (2002). Utilization of distillers grains from the fermentation of sorghum or corn in diets for finishing beet and lactating dairy cattle. J. Anim. Sci., 80: 1105-1111.

Archibeque, S.L.; Freetly, H.C. and Ferrell, C.L. (2008). Feeding distillers grains supplements to improve amino acid nutrients of lambs consuming moderate-quality forage. J. Anim. Sci., 86, 691-701.

Arelovich, H.M.; F.N.Owens; G.W. Hom and J.A. Vizcarra (2000). Effect of supplemented zinc and manganese on ruminal fermentation, forage intake and digestion by cattle fed praine hay and urea. J. Anim. Sci., 78: 2972-2979.

Boots, L.R.; Cerist, W.L.; Davis, D.R.; Brum, E.W. and Ludwick, T.M. (1969). Effect of age, body weight, stage of gestation and sex on plasma glutamic-oxaloacetic and glutamic- pyrovic transaminase activities in mature Holstein Cattle. J. Dairy Sci., 52, 2: 211.

Carvalho, L.P.F.; Melo, D.S.P.; Pereira, C.R.M.; Rodrigues, M.A.M.; Cabrita, A.R.J. and Fonseca, A.J.M. (2005). Chemical composition, in vivo digestibility, $\mathrm{N}$ degradability and enzymatic intestinal digestibility of five protein supplements. Animal Feed Science and Technology, 119, 171178. 
Church, DC. And Pand, W.G. (1982). Basic animal nutrition and feeding $2^{\text {nd }}$ ed. Johnwiley and Sons, New York, U.S.A.

Cornell, A.G.; Badawill, C.J. and David, M.M. (1949). Determination of Serum proteins by means of the buriet reaction. J. Biochem., 177: 551.

Drupt, E. (1974). Cdorimetric determination of albumin. Journal of Biocology, 9: 777 .

Duncan, D.B. (1955). The multiple range and $F$ test, Biometrics, 11: 1-45.

Eadie, J.M.P.; N. Hobson and S.O. Mann (1967). A note on some comparisons between the rumen content of barley fed steers and that of young calves fed on high concentration rations.J.Anim. Prod., 9: 247.

El-Nahas, H.M. (2010). Effect of zinc sulfate and /or manganese sulfate supplementations on Friesian calves performance. J. Anim. and Poultry Prod. MansouraUniv., Vol.7 (11): 575-588.

Estrade-Angulo, A.; Contreras, G.; Perez, A.; Gamer, G.; Lozano, O.; Rios, FG and Vazquez, E. (2007). Effect of dried distillers grains substituting for corn-soybean meal on growth and feed intake of Pelibuey sheep. J. Anim. Sci., 85; 572.

Etman, K.E.I.; A. M. Zied; T.I.El-Monayer; S.B. Mehany and Galila, A.M.A. Darwish (2012). Utilization of new nutritional resources in ruminant feeding 3)Effect of using dried distillers grains with solubles (DDGS) as protein source in rations for lactating Friesian cows. J. Animal and Poultry Prod., MansouraUniv., Vol.3 (11): 523-536, Egypt.

Etman, K.E.I.; T.I. El-Monayer; A.M.M. Zeid; Ebtehag, I.M. Abou-Elenin and S.K. Sayed (2011). Utilization of new nutritional resources in ruminant feeding: 2) Effect of using dried distillers grains with solubles (DDGS) as protein source in rations for fattening buffalo calves. J. Animal and Poultry Prod., MansouraUniv., Vol. 2 (6): 201-215.

Etman, K.E.I.; A.M.M. Zeid and T.I El-Monayer (2010). Utilization of new nutritional resources in ruminant feeding: 1) Effect of using dried distillers grains with solubles (DDGS) in rations for fattening Friesian calves. J. Anim and Poultry Prod., MansuraUniv., Vol.1 (12): 659-669.

Faichney, G.J. and G.A. White (1977). Formaldehyde treatment of concentrate diets for sheep. 1-Partition of digestion of organic matter and nitrogen between the stomac and intestine. Aust. J. Agric. Res., 28: 1055.

Fawcett, J.K. and J.E. Scott (1960). Colorimetric determination of urea. An. J. Clin. Path., B, 156.

Felix, T.L.; H.N. Zerby; S.J. Moeller and S.C. Loerch (2012). Effect of increasing dried distillers grains with soluble on performance carcass characteristics and digestibility of feedlot lambs. J. Anim. Sci., 90: 1356-1363.

Ham, G.A.; Stock, R.A.; Klopeenstein, T.J.; Larson, E.M.; Shain, D.H. and Huffman, R.P. (1994). Wet corn distillers byproducts compared with dried corn distillers grains with solubles as a source of protein and energy for ruminants. J. Anim. Sci., 72, 3246-3257.

Held, J. (2006). Feeding soy hulls and dried distillers grains with solublesto sheep. South DakotaStateUniversity, Cooperatine Extension Service, Ex Ex2052 Access at http://agbiopubs.solstate 
Johnson, V.W. and J.D. Sutton (1968). The continuous recording of $\mathrm{pH}$ in the bovin rumen. Br. J. Nutr., 22: 303.

Kornegay, E.T.; Z. Wany; C.M. Wood and M.D. Lindemann (1997). Supplemental chromium piolinate: Influence nitrogen balance, dry matter, digestibility and carcass traits in growing finishing pigs. J. Anim. Sci., 75: 1319.

Kumar, N.U.; B.Singh and D.N. Verma (1980). Effect of different levels of dietary protein and energy on growth of male buffalo calves. Ind. J. Anim. Sci., 51: 513.

Leupp, J.L.; G.P. Lardy; K.K. Karges; M.L. Gibson and T.S. Caton (2009). Effect of increasing level of corn distiller dried grains with solubles on intake, digestion and ruminal fermentation in steers fed seventy percent concentrate diets. J. Anim. Sci., 87: 2906.

Lopez, O.C.; R. Bodas; N. Prieto; P.Fruto; S. Andress and F.J. Giralez (2010). Vinasse added to concentrate for fattening lambs: Intake, animal performance and carcass and meat characteristics. J. Anim. Sci., 89: 1153-1162.

May, M.L.; M.J. Quinn; B.E. Depenbusch; C.D. Reinhard; L. Gibson; K.K. Karges; N.A. Cole and J.S. Drouillard (2009). Dried distillers grains with solubles reduced corn silage level in beet finishing diet. J. Anim. Sci., Vol. 10: 2527.

Mohi- El-Din, A.M.A.; Fathia, A.I. and E.E. Ragheb (2008). Effect of using natural feed additives on feed utilization and growth performance of growing Friesian calves. Egyptian. J. Nutr. and Feeds, 11 (1): 159-170.

Neary, M.; R. Lemenager and S. Lake (2006). Value of distiller grains as a feed for sheep. Purdue Univ., Purdue Extension, ID-330.

NRC (2007). Nutrient requirements of sheep. Academy of Science. National Research Council, Washington, D.C.

O'Hara, A.S.; Tanner, A.; McAllister, T.A.; Gibb, D.J. Van Herk, F. and Chaves, V.A. (2011). Effect of low and high oil corn distillers grains on rumen fermentation of lamb. Anim-Prod. Sci., 51, 708-716.

Radev, V. (2012). Effect of dietary supplementation of dried distillers grains with solubles on some rumen fermentation parameters in yearling sheep. Agriculture Science and Technology, Vol.4, No.3, pp. 241-245.

Reed, J.J.; Lardy, G.P.; Bauer, M.L.; Gibson, M.L. and Caton, J.S. (2006). Effect of season and inclusion of corn distillers dried grains with solubles in creeps feed on intake, microbial protein synthesis and efficiency, ruminal fermentation, digestion and performance of nursing calves grazing native range in south western, North Dekota. J. Anim. Sci., Vol. 84 (8).

Reitman, S. and S. Frankel (1957). A colorimetric method for determination of serum glutamic oxaloacetic and glutamic pyruvic transminases. Amer. J. Clin. Path., 28: 56-63.

Sahin, T.; O.Kaya; D.AksuElmali and I.Kaya (2013). Effect of dietary supplementation with distillers dried grains with solubles in growing lambs on growth nutrient digestibility and rumen parameters. Revue Med. Vet., 164, 4: 173-178. 
SAS (2000). Statistical Analysis System, User Guide Statics, SAS Institute Inc., Cary N.C., USA.

Schauer, C.; M. Stamm; T.Maddock and P. Berg (2008). Feeding of DDGS in lamb rations. Sheep and Goat Research Journal, Vol. 23.

Shakweer, I.M.E.; A.A.M.El-Mekass and H.M-El-Nahas (2010). Effect of zinc supplementation as zinc sulfate or zinc methionine on Friesian calves performance. Egyptian. J. Anim. Prod., 47 (1): 23-36.

Shauer, C.S.; Berg, P.B.; Stamm, M.; Stecher, D.M.; Pearson, D. and Drolc, D. (2006). Influence of dried distillers grains of feed lot performance and carcass characteristics of finishing feedlot. Western Dakota sheep and Beef Day, 47, 34-37.

Shwerab, A.M.; M.S. Khalel; A.A.Hassan;Amany,A. Khayyal and M.H. Yacout (2010).Optimizing the use of corn dried distillers grains with solubles in sheep production. Egyptian J.Nutrition and Feeds,13(3): 415-431.

Vander Pol, K.J.; G. Erickson, T.Klopfenstein and M. Greenquist (2005). Effect of level of wet distillers grains on feedlot performance of finishing cattle and energy value relative to corn. J. Anim. Sci., 83 (suppl.2): 25.

Wertz -Lutz, A.; Zelinsky, R. and Held, J. (2007). Effects of increasing the dietary energy density by replacing grass hay with soybean hulls and dried distillers grains with solubles on nutrient digestibility and rumen fermentation. SDSU, Department of Animal and Range Science, Depart. Res. Rep., pp: 01.

Young, D.S. (1990). Effect of drug on clinical laboratory tests. $3^{\text {rd }}$ ed. AACC Press, Washington, D.C., USA.

Yousef, H.M. and A.A. Zaki (2001). Effect of barley radical feeding on body weight gain and some physiological parameters of growing Friesian crossbred calves. Egyptian. J. Nutrition and Feeds, 4 (special issue): 465-472.

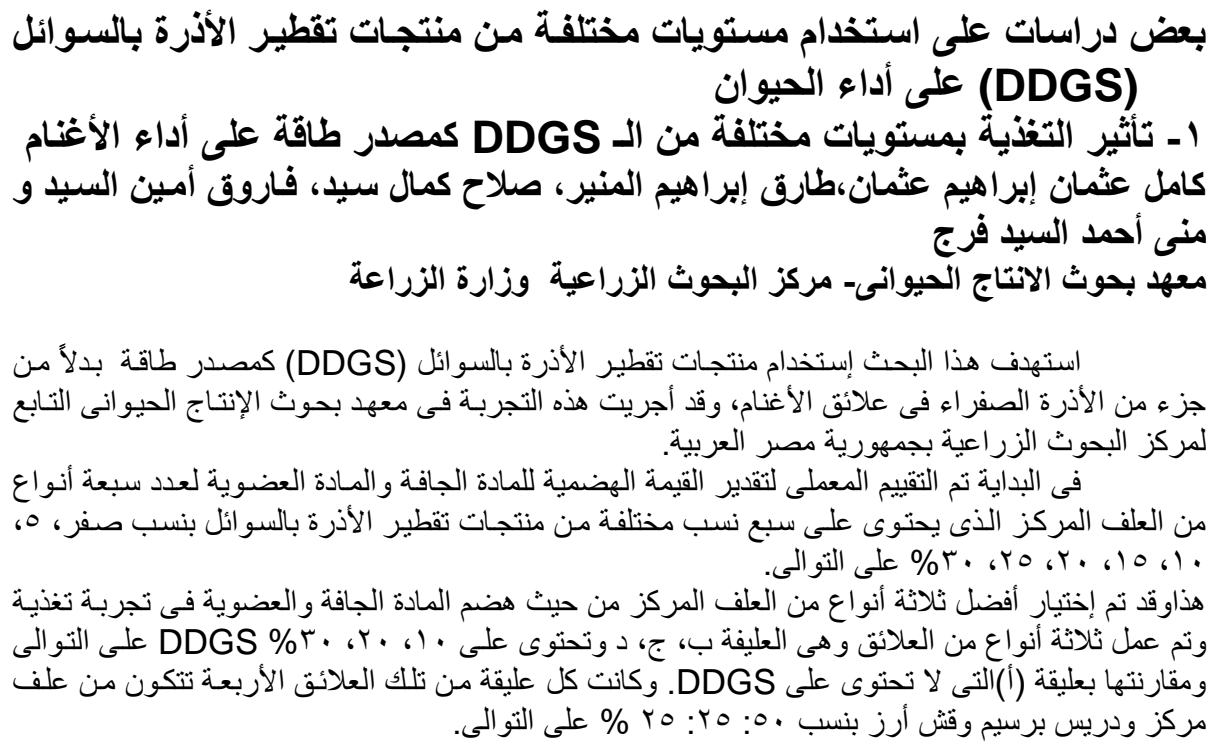




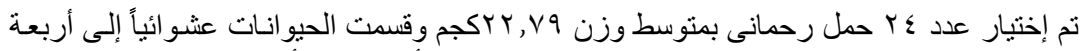

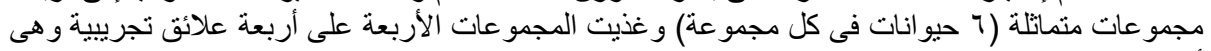

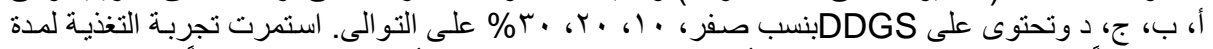

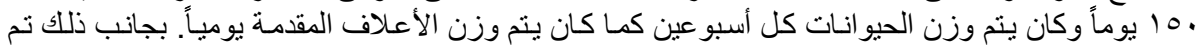

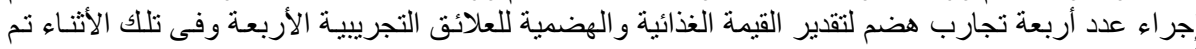

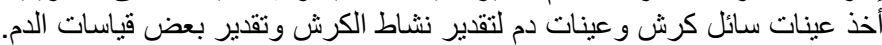

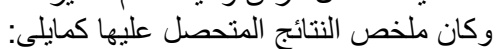

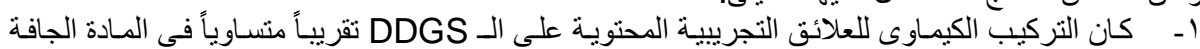

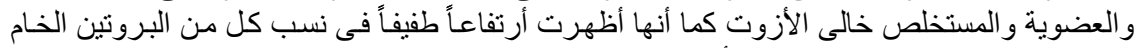
و والدهن مع إنخفاض بسيط فى نسبة الألياف الخام.

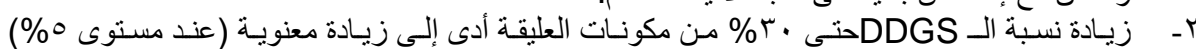

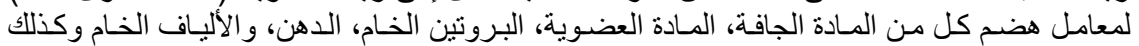

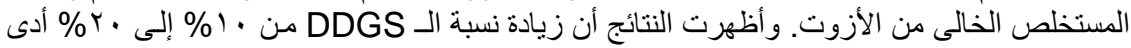

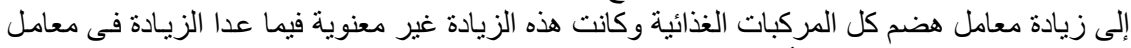
هضم المستخلص الخالي من الأزوت.

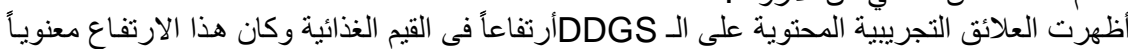

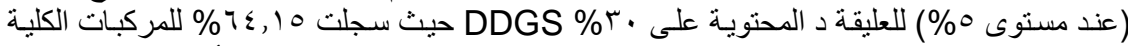

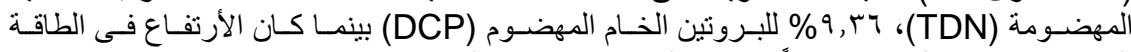

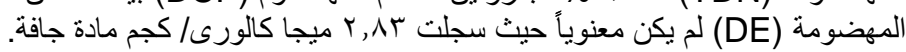

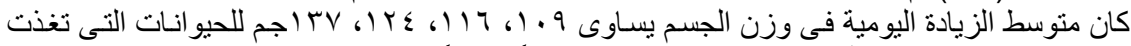

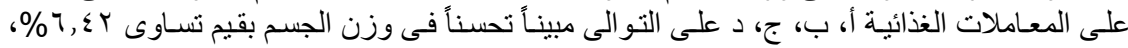

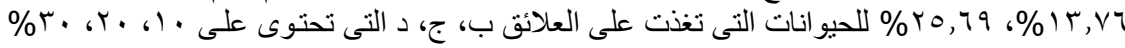
DDGS

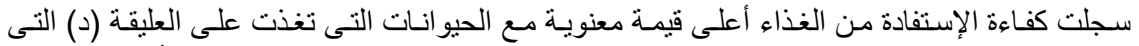

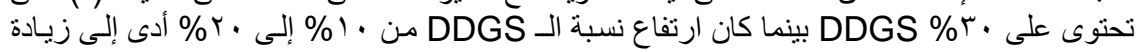
الإستفادة من الغذاء زيادة غير معنوية ولم تؤثر زيادة نسبة الـ DDGS على كفاءة الإستفادة من بروتين

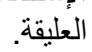

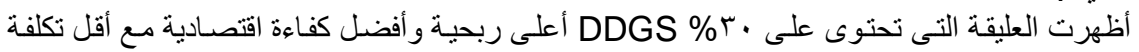

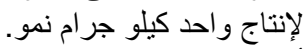

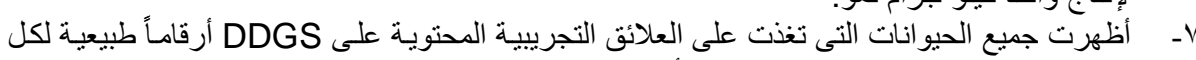

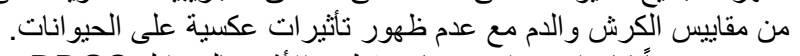

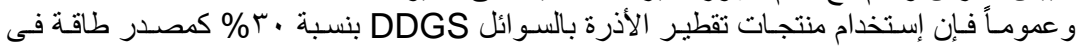

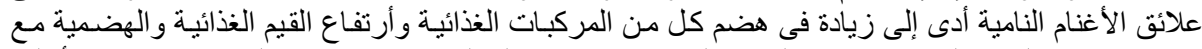

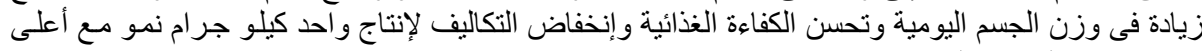
كفاءة اقتصادية وربحية.

كلية الزراعة - جامعة المنصورة كلية الزراعة - جامعة القاهرة 
Etman, K.E.I. et al. 